\title{
EFFECT OF AGE ON HEARTWOOD / SAPWOOD RELATIONSHIP, EXTRACTIVE CONTENT, AND PERMEABILITY OF TEAK WOOD
}

\author{
Wagner Davel Canal ${ }^{1 *}$, Ana Márcia Macedo Ladeira Carvalho², Angélica de Cássia Oliveira Carneiro ${ }^{3}$, Graziela \\ Baptista Vidaurre ${ }^{4}$, Fabiana Paiva de Freitas ${ }^{5}$, Mateus Alves de Magalhães ${ }^{6}$ \\ 1*Universidade Federal de Viçosa, Programa de Pós-Graduação em Ciência Florestal, Viçosa, Minas Gerais, Brasil - \\ wagner.d.canal@gmail.com \\ ${ }^{2}$ Universidade Federal de Viçosa, Programa de Pós-Graduação em Ciência Florestal, Viçosa, Minas Gerais, Brasil - ana.marcia@ ufv.br \\ ${ }^{3}$ Universidade Federal de Viçosa, Programa de Pós-Graduação em Ciência Florestal, Viçosa, Minas Gerais, Brasil - \\ cassiacarneiro1@gmail.com \\ ${ }^{4}$ Universidade Federal do Espírito Santo, Departamento de Ciências Florestais e da Madeira, Jerônimo Monteiro, Espírito Santo, Brasil - \\ grazividaurre@gmail.com \\ ${ }^{5}$ Universidade Federal de Viçosa, Programa de Pós-Graduação em Ciência Florestal, Viçosa, Minas Gerais, Brasil - fabianapf@ hotmail.com \\ ${ }^{6}$ Universidade Federal de Viçosa, Programa de Pós-Graduação em Ciência Florestal, Viçosa, Minas Gerais, Brasil - \\ mateusmagalhaes91@gmail.com
}

Received for publication: 23/04/2018 - Accepted for publication: 19/05/2020

\begin{abstract}
Resumo
Efeito da idade na relação cernelalburno, teor de extrativos e permeabilidade da madeira de teca. Em virtude das diferenças fisiológicas nas fases juvenil e adulta da madeira de teca, ocorrem diferenciações na impregnação por materiais extrativos ao longo das regiões do cerne, supondo-se que também haja significativa variação na permeabilidade desse material. Dessa forma, o trabalho teve como objetivo avaliar a influência da idade na relação cerne/alburno (C/A), permeabilidade e teores de extrativos da madeira de Tectona grandis L.f. Foram avaliadas 4 idades (10, 12, 14 e 16 anos) e 4 árvores (repetições), totalizando 16 unidades amostrais. Foram determinados a relação C/A, teor de extrativos e permeabilidade da madeira, além de ter sido selecionados corpos de provas representativos da permeabilidade média e máxima dentre todas as idades para o cálculo de suas porosidades. A relação C/A foi crescente ao longo das idades de 10 e 16 anos e o teor de materiais extrativos aumentou até os 14 anos. Constatou-se elevada heterogeneidade entre os valores de permeabilidade da madeira em todas as idades analisadas, sendo que uma das possíveis explicações para este fato se deve à presença de tiloses em locais variados no tronco e disposição dos poros ao redor dos anéis de crescimento. Palavras-chave: diferenças fisiológicas da madeira de teca; variação na permeabilidade; tiloses.
\end{abstract}

\begin{abstract}
Due to the physiological differences in the juvenile and adult phases of teak wood, differentiation occurs in the impregnation by extractive materials along the heartwood regions, assuming that there is also a significant variation in the permeability of this material. Thus, the study aimed to evaluate the influence of age on the heartwood / sapwood ratio (H/S), permeability, and extractives content of Tectona grandis L.f wood. Four ages $(10,12,14$, and 16 years) and four trees (repetitions) were evaluated, totaling 16 samples. The H/S ratio, extractive content, and wood permeability were determined, in addition to the average and maximum permeability among all ages selected for calculation of their porosity. The H/S ratio increased over the ages of 10 and 16, and the content of extractive materials increased until the age of 14 . There was a high heterogeneity between the permeability values of the wood at all ages analyzed, and one of the possible explanations for this fact is the presence of tyloses in different places on the trunk and the arrangement of the pores around the growth rings.
\end{abstract}

Keywords: physiological differences of teak wood; permeability variation; tyloses.

\section{INTRODUCTION}

Teak (Tectona grandis L.f.) is a large tree belonging to the Lammiaceae (formerly Verbenaceae) family. Recently introduced to Brazil, the teak trees are native to the tropical forests located between $10^{\circ} \mathrm{S}$ and $25^{\circ} \mathrm{N}$ in the Indian subcontinent and Southeast Asia, mainly in India, Burma, Thailand, Laos, Camboja, Vietnan, and Java (TONINI et al., 2009). According to Bonduelle et al. (2015), the teak wood is suitable for a wide variety of applications, due to its physical stability and natural durability at different harvesting ages. Regarding the teak tree physiological growth, Taylor et al. (2002) highlights that the heartwood can be distinguished from sapwood by its darker color and the increased resistance to xylophage organisms, due to the impregnation of extractive materials in the area during the tree development.

FLORESTA, Curitiba, PR, v. 50, n. 4, p. 1698 - 1706, out/dez 2020.

Canal, W. D. et.al.

ISSN eletrônico 1982-4688 
Due to physiological differences generated by the teak heartwood formation process, Paes et al. (2015) observed that besides the differences in resistance to biodeterioration in the heartwood and sapwood areas, there are also changes to the wood physical resistance. Furthermore, Vidaurre et al. (2011) consider that differences in the production of adult and juvenile wood during the development of any rapid growth specie, such as the teak, also results in different responses when it is submitted to different beneficiation processes.

Given the differentiation in impregnation of extractive materials through the different regions of the teak wood heartwood, it is reasonable to hypothesize that there might also be variations in the permeability of fluids in this material. However, the effect of different harvesting ages on the teak wood permeability has not been widely studied and discussed in the literature. Therefore, the objective of this study is to investigate the effect of the Tectona gradis age on the heartwood/sapwood ratio, extractive contents, and permeability.

\section{MATERIALS AND METHODS}

The teak wood used in this study was obtained from the commercial crops of a forestry company in Nova Maringa, in the Brazilian state of Mato Grosso.

\section{Tree sectioning, heartwood/sapwood ratio, and permeability}

The selected trees were at 4 different ages $(10,12,14$, and 16 years old), and planted with an average spacing of $3 \mathrm{~m} \mathrm{x} 2 \mathrm{~m}$. Four trees were selected for each age and cut into $6.9 \mathrm{~m}$ long logs. Discs of $15 \mathrm{~cm}$ diameter were obtained from each $\log$ at $0.5 \mathrm{~m} ; 2.3 \mathrm{~m} ; 4.6 \mathrm{~m}$; and $6.9 \mathrm{~m}$ from the base (Figure $1 \mathrm{~A}$ ).

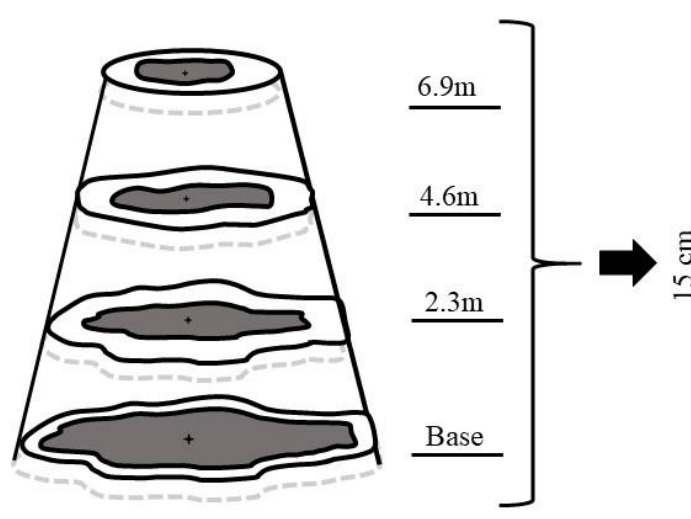

(A)
(B)

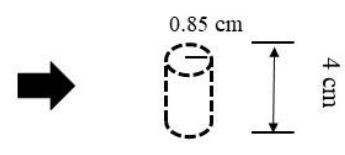

(C)

\footnotetext{
$+\quad$ Core

Heartwood

Sap-wood
}

Figure 1. Sectioning of trees (A), characterization of the heartwood and sapwood regions and removal of samples for the wood permeability (B) and dimensioning of wood permeability samples (C).

Figura 1. Seccionamento das árvores (A), caracterização das regiões de cerne e alburno e retirada dos corpos de prova para realização da permeabilidade da madeira (B) e dimensionamento dos corpos de prova de permeabilidade da madeira $(\mathrm{C})$.

In order to observe the color of the heartwood and sapwood (Figure 1B), the transversal surfaces of the discs were initially polished with sandpaper of different abrasiveness $\left(60,80\right.$, and 100 granules per $\left.\mathrm{cm}^{2}\right)$. This procedure was carried out in order to observe the color corresponding to the heartwood and sapwood regions of the teak, as shown in Figure 1B. Subsequently, the discs were measured to obtain their total diameter and the heartwood diameter. The measurement procedure consisted of drawing 2 perpendicular lines, from one extremity of the disc to the other, passing through the core center, and measuring their length with a ruler (precision: 0.1 $\mathrm{cm})$. The heartwood/sapwood ratio $(\mathrm{H} / \mathrm{S})$ was determined as described in Pereira et al. (2013): 
in which,

$$
\mathrm{H} / \mathrm{S}=\frac{\mathrm{Dh}^{2}}{\mathrm{D}^{2}-\mathrm{Dh}^{2}}
$$

Dh: diameter of heartwood $(\mathrm{cm})$; and

D: diameter of the disc without bark $(\mathrm{cm})$.

The wood permeability was measured from a cylindrical sample of $0.85 \mathrm{~cm}$ radius and $4 \mathrm{~cm}$ length (Figure 1C), which were collected in parallel from the diametrical strip of each disc at $0 \%, 45 \%$, and $75 \%$ of the selected area (Figure 1B). The wood permeability at atmospheric pressure was calculated based on Darcy's Law, following the method described in Freitas et al. (2019). The experimental apparatus consisted of 4 air flowmeters, connected in series to a vacuum pump (Figure 2) with the following flow ranges: 0.04 to 0.50 LPM; 0.50 to 2.50 LPM; 2.5 to $5.0 \mathrm{LPM}$; and 5.0 to $25.0 \mathrm{LPM}$. The pressure applied was $-3 \mathrm{inHg}$ and the airflow was measured with the flowmeter at the lowest measurement range.

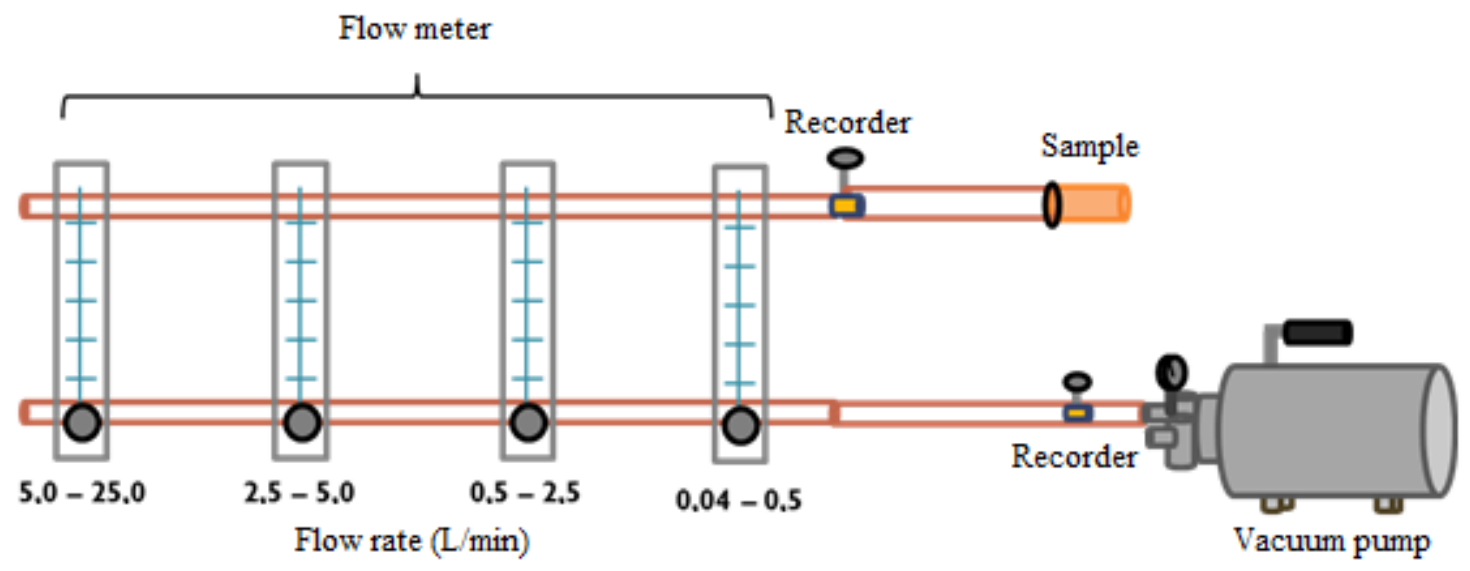

Figure 2. System used to measure the wood permeability to atmospheric air (FREITAS et al., 2019). Figura 2. Sistema utilizado para medição da permeabilidade da madeira ao ar.

Air flow and pressure gradient were used to calculate the wood permeability using the following equation (Freitas et al., 2019):

$$
K g=\frac{\text { Q. L.Pi }}{\text { A. } \Delta \text { P.Pm }}
$$

In which: $\mathrm{Kg}=$ permeability $\left(\mathrm{cm}^{2} / \mathrm{atm} . \mathrm{s}\right) ; \mathrm{Q}=$ air volumetric flow $\left(\mathrm{cm}^{3} / \mathrm{s}\right) ; \mathrm{L}=$ length of the sample $(\mathrm{cm})$; $\mathrm{Pi}=$ entry / atmospheric pressure $(\mathrm{atm}) ; \mathrm{A}=$ sample's transversal area, perpendicular to the airflow $\left(\mathrm{m}^{2}\right) ; \Delta \mathrm{P}=$ pressure drop (atm); $\mathrm{Pm}=$ mean pressure throughout the sample $(\mathrm{atm})$.

The mean values for the wood permeability and heartwood/sapwood ratio were determined by the volume of the $\log$ in between 2 consecutive discs, as described in Pereira et al. (2013).

Macroscopic analysis of wood porosity

In order to observe the continuity of the vessel elements, specimens demonstrating the average and maximum permeability of the wood were sectioned every $0.3 \mathrm{~cm}$ in the direction of the fibers and photographed in an equipment containing their own lighting, as shown in Figure 3.

FLORESTA, Curitiba, PR, v. 50, n. 4, p. 1698 - 1706, out/dez 2020.

Canal, W. D. et.al.

ISSN eletrônico 1982-4688 

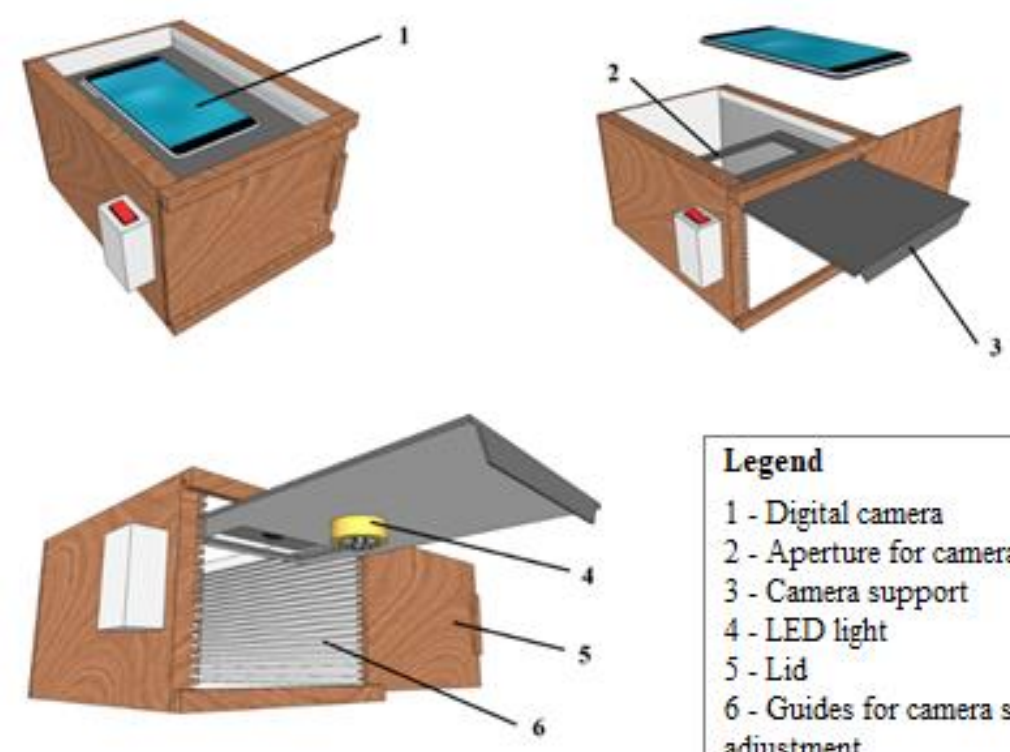

\begin{tabular}{l}
\hline Legend \\
1- Digital camera \\
2- Aperture for camera placement \\
3 - Camera support \\
4 - LED light \\
5 - Lid \\
6 - Guides for camera support \\
adjustment
\end{tabular}

Figure 3. Box with LED light illumination and support for photographic cameras.

Figura 3. Caixa com iluminação de luz de LED e suporte para câmeras fotográficas.

In order to observe the continuity of vase elements, the samples used to determine mean and maximum permeability were sectioned at $0.3 \mathrm{~cm}$ spacing in the direction of the fibers and photographed in an equipment specially built for this purpose (Figure 3). It consisted of a box made from wood and metal, sealed to avoid external light interference and equipped with a LED light placed under the camera support to obtain more luminous homogeneity. The images were captured using a 9.6-megapixel camera and metal guides were fixed to the sidewalls to allow for different placements of the camera support, guarantying different depth levels and improved quality images.

Four images were taken for each sample, being one image for each $0,3 \mathrm{~cm}$ long section. The images were processed using Matlab software. Unobstructed pores shown in the images were considered empty spaces, and the porosity was calculated based on the sample base area $\left(2.27 \mathrm{~cm}^{2}\right)$.

\section{Extractive materials content}

Leftovers from the wood discs were ground and sifted through sieves of 40 and 60 mesh. The fraction of material that passed through the 40 mesh sieve and was retained by the 60 mesh sieve was used to determine the extractive materials content (ASTM, 1982).

Subsequently, the absolute dry content of the ground samples was determined following the standard procedure TAPPI 264 om-88 (TAPPI, 2001). The extractive materials content was determined in duplicates, using the total extractive method as described in the standard procedure TAPPI 204 om-88 (TAPPI, 2001). Ethanol/benzene was substituted by ethanol/toluene.

\section{Experimental design}

The experimental data was analyzed using analysis of variance (F-test), following a completely randomized design (age versus $\mathrm{H} / \mathrm{S}$ ratio, extractive material content and wood permeability). The significant data was adjusted to a regression model, and the angular coefficients were tested using a T-test. The model coefficient of determination $\left(\mathrm{R}^{2}\right)$ was used to select the models that best explained the wood properties in function of the tree age at the time of harvesting.

\section{RESULTS}

The models built based on the H/S ratio and extractive material content in relation to age were adjusted to a quadratic regression and had a $\mathrm{R}^{2}$ of 0.7885 and 0.9647 , respectively.

FLORESTA, Curitiba, PR, v. 50, n. 4, p. 1698 - 1706, out/dez 2020.

Canal, W. D. et.al.

ISSN eletrônico 1982-4688 


\section{Heartwood/sapwood ratio}

Figure 4 presents the teak wood $\mathrm{H} / \mathrm{S}$ ratio as a function of age.

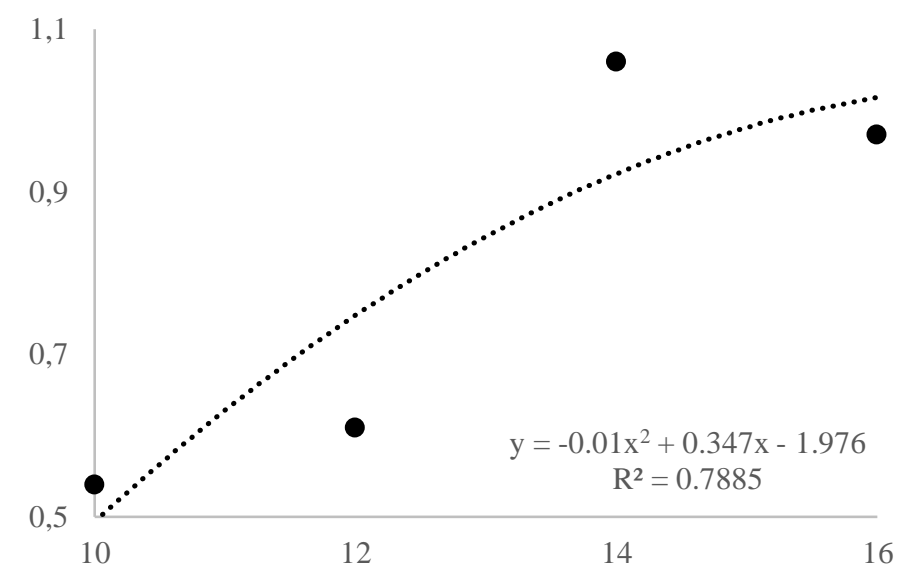

Figure 4. Heartwood / sapwood ratio of teak wood as a function of age.

Figura 4. Relação cerne/alburno da madeira de teca em função da idade.

It is possible to observe from the adjusted curve equation in Figure 4 that there is a tendency for the H/S ratio to increase with increasing ages between 10 and 14 years of age.

Extractive materials content

Figure 5 presents the average values of extractive material content as a function of age.

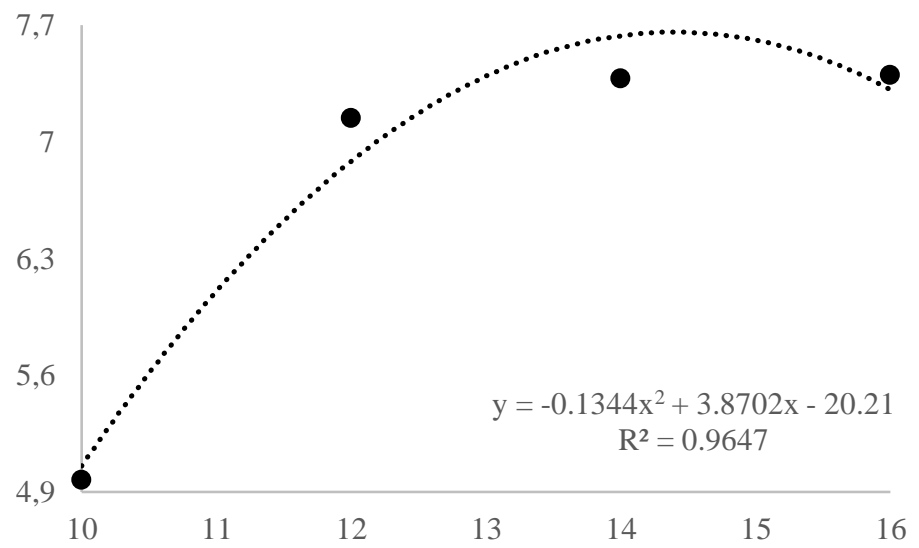

Figure 5. Extractive materials content of as a function of age.

Figura 5. Teor de materiais extrativos em função da idade.

The curve in Figure 5 shows that the extractive materials content increased until 14 years of age and showed a tendency to decrease from this age onwards.

Wood permeability

Table 1 presents the average values of the teak wood permeability as a function of age of harvesting.

Table 1. Average values of permeability according to the age of harvesting.

Tabela 1. Valores médios de permeabilidade em função da idade de colheita.

FLORESTA, Curitiba, PR, v. 50, n. 4, p. 1698 - 1706, out/dez 2020.

Canal, W. D. et.al.

ISSN eletrônico 1982-4688 


\begin{tabular}{ccccc}
\hline & \multicolumn{4}{c}{ Age of harvesting (years) } \\
\cline { 2 - 5 } Permeability & $\mathbf{1 0}$ & $\mathbf{1 2}$ & $\mathbf{1 4}$ & $\mathbf{1 6}$ \\
\cline { 2 - 5 } (cmªir/cm.atm.s) & 123.65 & 60.14 & 120.49 & 139.32 \\
& $(129.52)^{*}$ & $(28.41)$ & $(49.60)$ & $(51.18)$ \\
\hline
\end{tabular}

*Values in parenthesis represent the mean standard deviation

The high standard deviations presented in Table 1 indicate that is very likely that the influence of age on permeability is not statistically significant. Therefore, the data was not fitted into a regression model. According to Paes et al. (2016), the variation in permeability is due to the temporal differences from the impregnation of extractive materials during the wood formation. In addition, the formation of early and late logs and the consequent dimensional differentiation between the anatomic elements can present distinct characteristics. That said, it is possible to conclude that aging of the log of any wood can promote significant differences in physical properties along the log radius.

Wood analysis of macroporosity

Table 2 presents the processed images of the samples sectioned at $0.3 \mathrm{~cm}$ spacing and shows both the medium and maximum values of permeability between all ages considered (10, 12, 14, and 16 years).

Table 2. Porosity in the longitudinal direction of the specimens from permeability analysis.

Tabela 2. Porosidade no sentido longitudinal dos corpos de prova da análise de permeabilidade.

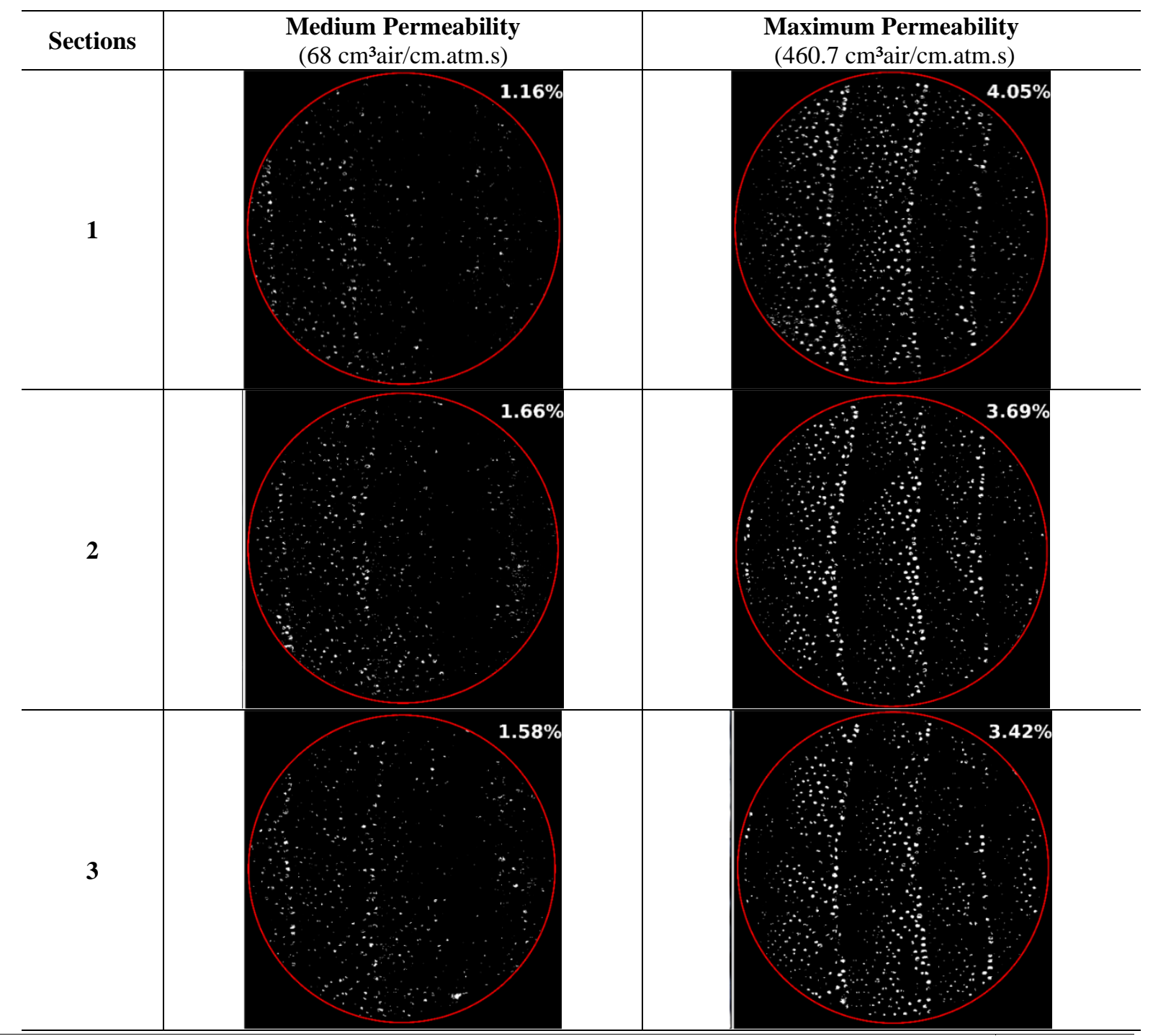

FLORESTA, Curitiba, PR, v. 50, n. 4, p. 1698 - 1706, out/dez 2020.

Canal, W. D. et.al.

ISSN eletrônico 1982-4688 


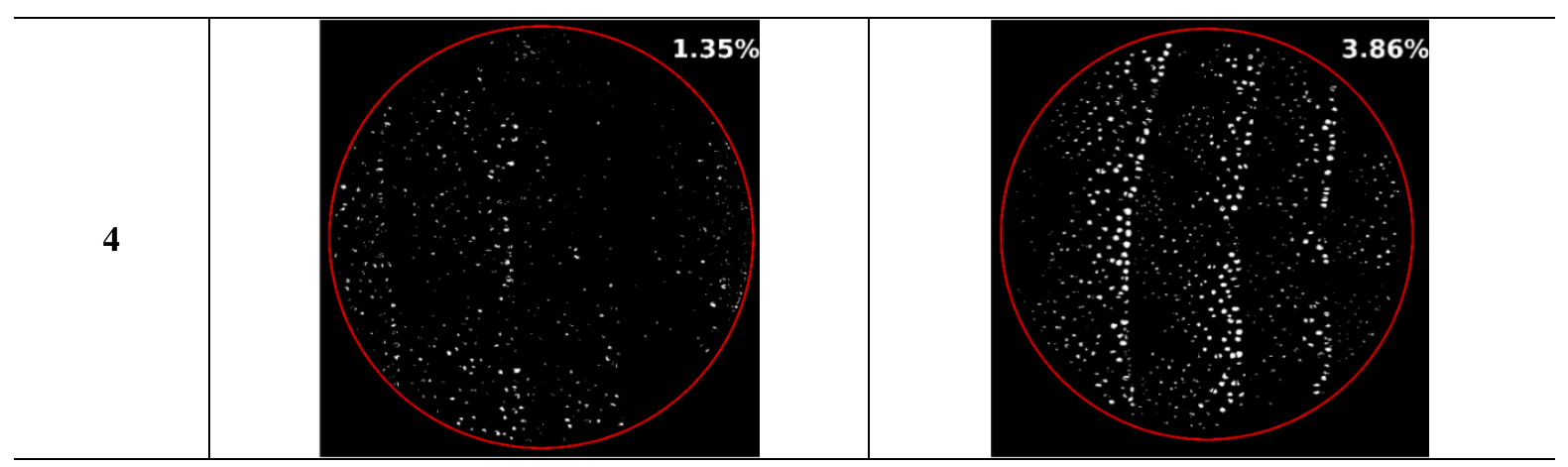

A thorough analysis of Table 2 reveals that the teak wood porosity do not follow a continuous path in the longitudinal direction. This is because in some images, the pores are shown to be obstructed, and in others, they are unobstructed in the axial axis. Therefore, it is possible to observe that the high variation of the teak wood permeability values is due to the irregularities in the fluids flowing between the conducting vessels.

\section{DISCUSSION}

\section{Heartwood/sapwood ratio}

In this study, it was found that for teak wood, there is a tendency for the H/S ratio to increase with increasing age of harvesting (Figure 4). As the tree ages, the amount of heartwood in the log is expected to increase, and the added value of the wood increases as well. According to Pereira et al. (2013), due to the high physical and mechanical resistance of the heartwood, these increased values for the log is a very desirable characteristic for production of furniture and use in construction. Moya et al. (2014) reported that in teak wood, the formation of heartwood starts between the ages of 4 and 6 years or when its total diameter reaches approximately $10 \mathrm{~cm}$. Leite et al. (2011) studied the teak wood at later ages and created models for the growth of teak heartwood based solely on the tree diameter tapering, since that heartwood tends to increase exponentially with increasing of a diameter at $1.3 \mathrm{~m}$ height (dap).

Moya and Calvo-Alvarado (2012) studied the effect of monthly rainfall on both the total wood and the heartwood diameter growth of the teak and concluded that this climate variable is one of the main factors that induce heartwood formation in teak wood trees. In addition, Moya and Berrocal (2010) stated that the heartwood growth can also be influenced by the extractive material content and correlate with the wood colorimetric parameters. According to Garcia and Marinonio (2016), heartwood formation is related to the teak wood physical properties, as a consequence of impregnation of hydrophobic extractive materials during the aging process and death of $\log$ cells.

\section{Extractive Materials Content}

Micco et al. (2016) pointed out that during the aging process and death of parenchyma cells, there is higher production of extractive materials and impregnation of these compounds on the walls of the fibers and other anatomic elements of the wood. Niamké et al. (2011) affirmed that the production of lipid material increases significantly with the aging of teak trees. Garcia and Marinonio (2016) highlighted that the presence of extractive materials compounds in teak wood is not only responsible for its characteristic coloration but also to its natural durability, dimensional stability, and water resistance. Therefore, due to these chemical and physical properties of teak wood, Angeli (2019) affirmed that the presence of a chemical substance called rubber, which reduces water absorption, wood surface lubrication, resistance to acids, and protection to corrosion of nails and screws. In addition, studies conducted by Nidavani and Mahalakshmi (2014) found a large concentration of tectoquinone in teak heartwood, which confers natural durability to the wood.

In this study, it was observed that the production of extractive material is also related to the wood color change and not only to the formation of tyloses and obstruction of conductive vessels by phenolic compounds, as suggested by Micco et al. (2016). This fact can be verified by the large variation of permeability values in internal and external regions of the log in the radial direction, which does not guarantee an exclusive formation of tyloses in the heartwood region.

Wood permeability

According to Micco et al. (2016), wood from leafy trees is expected to present a fluid flow at ages that guarantee higher percentages of sapwood, since younger logs are less developed the natural heartwood formation

FLORESTA, Curitiba, PR, v. 50, n. 4, p. 1698 - 1706, out/dez 2020.

Canal, W. D. et.al.

ISSN eletrônico 1982-4688 
process and obstruction of vessel by tyloses. However, although the logs used in this study are considered young, the ratio to sapwood and the high wood permeability at atmospheric pressure was not applied, given that this quality parameter presented a high variation. Therefore, one of the hypotheses for the high variation of permeability for this material can be due to the irregular process of heartwood formation in tree ring growth, in addition to the fact that some of the samples were collected close to the bark (75\% of the radius) with heartwood portions.

Baraúna et al. (2014) stated that the high variation of permeability values in tropical wood is mainly due to the heterogeneity of their anatomic properties across the growth rings. That being said, the anatomic characteristics of teak wood, such as pore distribution, can also explain the high variation of permeability values observed in this study. Chagas et al. (2014) observed that the pore distribution in teak wood occurs around the rings formed during the initial growth phase. Due to the irregular distribution of pores on the transversal plan of the wood, it is likely that some samples were collected from regions of higher or lower proportions of older logs and resulted in sampling of pores of different diameters. Therefore, the radial variation of teak wood pore distribution in this study may have had an influence on the measured permeability values. However, this property could also be related to a teak wood characteristic, since Chagas et al. (2015) also observed a high variability in permeability of on their study involving chromated copper arsenate (CCA) based preservative penetration.

\section{Analysis of wood macroporosity}

For some samples, it was not possible to distinguish empty and obstructed spaces along the fiber direction, which indicated total obstruction of pores and zero permeability $\left(0 \mathrm{~cm}^{3}\right.$ air $\left./ \mathrm{cm} . \mathrm{atm} . \mathrm{s}\right)$. While the samples with medium permeability $\left(68 \mathrm{~cm}^{3}\right.$ air/cm.atm.s) presented a difference of $30.12 \%$ between empty and obstructed spaces, the samples with maximum permeability $(460.7 \mathrm{~cm} 3$ air $/ \mathrm{cm} . \mathrm{atm} . \mathrm{s})$ presented a difference of $15.56 \%$. Despite the high variation observed in obstruction of pores (Table 2), it is reasonable to state that higher porosity results in greater permeability of teak wood. According to Albuquerque (2000), this alteration in porosity values is actually consistent with the presence of sealed perforation plates and gums or resinous materials in the vessels along the longitudinal direction, which can cause reduction of the Tectona grandis wood permeability.

\section{CONCLUSIONS}

- The heartwood/sapwood ratio increased between the ages of 10 and 16 years.

- The extractive material content increased until the age of 14 years.

- A high variability of the teak wood permeability was observed due to the pore distribution pattern and varying distribution of tyloses along the trunk or the irregularities between the heartwood and sapwood.

\section{ACKNOWLEDGEMENTS}

The authors express their gratitude to the Minas Gerais State Research Support Foundation (FAPEMIG) and the National Research and Development Council (CNPq) for the financial support, to Guavirá Industrial e Agroflorestal Ltda. for providing the material for this study, and the Panels and Wood Energy and Wood Properties Laboratories at the Federal University of Viçosa for the technical support.

\section{REFERENCE}

ALBUQUERQUE, C. E. C de. Efeito da secagem a $100{ }^{\circ} \mathrm{C}$ em membranas de pontoações de Pinus taeda $\mathrm{L}$. Floresta e Ambiente, Seropédica, v.7, n.1, p.129 - 136, 2000.

AMERICAN SOCIETY FOR TESTING AND MATERIALS. ASTM: standard methods of evaluating properties of wood-base fiber and particles materials. Philadelphia, 1982.

ANGELI, A. (ESALQ/USP). Tectona grandis. Disponível em: <http:// https://www.ipef.br/identificacao/tectona.grandis.asp> Acesso em: 10 nov. 2019.

BARAÚNA, E. E. P.; LIMA, J. T. L.; VIEIRA, R. S.; SILVA, J. R. M. da; MONTEIRO, T. C. Effect of anatomical and chemical structure in the permeability of "amapá" wood. Cerne, Lavras, v.20, n.4, p.529 - 534, 2014.

BONDUELLE, G.M.; IWAKIRI, S.; TRIANOSKI, R.; PRATA, J. G.; ROCHA, V. Y. Análise da massa específica e da retratibilidade da madeira de Tectona grandis nos sentidos axial e radial do tronco. Floresta, Curitiba, v.45, n.4, p.671 - 680, 2015.

FLORESTA, Curitiba, PR, v. 50, n. 4, p. 1698 - 1706, out/dez 2020.

Canal, W. D. et.al.

ISSN eletrônico 1982-4688 
CHAGAS, S. F.; EVANGEliSTA, W. V.; SilvA, J. C.; CARVALHO, A. M. M. L. Propriedades da madeira de teca de diferentes idades e oriundas de desbaste. Ciência da madeira, Pelotas, v.5, n.2, p.138 - 150, 2014.

CHAGAS, S. F.; EVANGELISTA, W. V.; SILVA, J. C.; PINHEIRO, M. A. Estudo da retenção e penetração de CCA na madeira de teca, visando uso como mourões tratados. Scientia Forestalis, Piracicaba, v.43, n.105, p.155 - 165, 2015.

FREITAS, F. P.; CARVALHO, A. M. M. L.; CARNEIRO, A. C. O.; VITAL, B. R.; MAGALHES, M. A.; XISTO, M. F. Hydrothermal treatment of eucalyptus grandis wood, Floresta, v.49, n.2, p.247- 256, 2019.

GARCIA, R. A.; MARINONIO, G. B. Variação da cor da madeira de teca em função da densidade e do teor de extrativos. Floresta e Ambiente, Seropédica, v.23, n.1, p.124 - 134, 2016.

LEITE, H. G.; OLIVEIRA-NETO, R. R. de; MONTE, M. A.; FARDIN, L.; ANCANTARA, A. M. de; BINOTI, M. L. M. S.; CASTRO, R. V. O. Modelo de afilamento de cerne de Tectona grandis L.f. Scientia Forestalis, Piracicaba, v.39, n.89, p.53 - 59, 2011.

MICCO, V. de; BALZANO, A.; WHEELER, E. A.; BAAS, P. Tyloses and gums: a review of structure, function and occurrence of vessel occlusions. IAWA Journal, v.37, n.2, p.186 - 205, 2016.

MOYA, R.; BERROCAL, A. Wood colour variation in sapwood and heartwood of young trees of Tectona grandis and its relationship with plantation characteristics, site, and decay resistance. Annals of Forest Science, v.67, n.1, p.109, 2010.

MOYA, R.; CALVO-ALVARADO, J. Variation of wood color parameters of Tectona grandis and its relationship with physical environmental factors. Annals of Forest Science, v.69, n.8, p.947 - 959, 2012.

MOYA, R.; BOND, B.; QUESADA, H. A review of heartwood properties of Tectona grandis trees from fastgrowth plantations. Wood Science Technology, v.48, n.2, p.411 - 433, 2014.

NIAMKÉ, F. B.; AMUSANT, N.; CHARPENTIER, J. P.; CHAIX, G.; BAISSAC, Y.; BOUTAHAR, N.; AMISSA, A. A.; KATIKOULIBALY, S.; JAY-ALLEMAND, C. Relationships between biochemical attributes (non-structural carbohydrates and phenolics) and natural durability against fungi in dry teak wood (Tectona grandis L. f.). Annals of Forest Science, v.68, n.1, p.201 - 211, 2011.

NIDAVANI, R. B.; MAHALAKSHMI, A. M. Teak (Tectona Grandis Linn.): renowned timber plant with potential medicinal values. International Journal of Pharmacy and Pharmaceutical Sciences, Academic Sciences, India, v.6, n.1, p.48 - 54, 2014.

PAES, J. B.; SANTOS, L. L.; SILVA, L. F.; MOTTA, J. P.; BRAZ, R. L.; LOMBARDI, L. R. Caracterização tecnológica da madeira juvenil de teca (Tectona grandis) visando a produção de móveis. Revista Brasileira de Ciências Agrárias, v.10, n.3, p.437 - 442, 2015.

PAES, J. B.; GUERRA, S. C. S.; SILVA, L. F. da; OLIVEIRA, J. G. L. de; TEAGO, G. B. S. Efeito do teor de extrativos na resistência natural de cinco madeiras ao ataque de cupins xilófagos. Ciência Florestal, Santa Maria, v.26, n.4, p.1259 - 1269, 2016.

PEREIRA, B. L. C.; OLIVEIRA, A. C.; CARVAlHO, A. M. M. L.; CARNEIRO, A. C. O.; VITAL, B. R.; SANTOS, L. C. Correlações entre a relação Cerne/Alburno da madeira de eucalipto, rendimento e propriedades do carvão vegetal. Scientia Forestalis, Piracicaba, v.41, n.98, p.217 - 225, 2013.

TAPPI - Technical Association of the Pulp and Paper Industry. TAPPI test methods T 204 om-88: solvent extractives of wood and pulp. In: TAPPI Standard Method. Atlanta: 2001. CD-ROM.

TAPPI - Technical Association of the Pulp and Paper Industry. TAPPI test methods T 264 om-88: preparation of wood for chemical analysis. In: TAPPI Standard Method. Atlanta: 2001. CD-ROM.

TAYLOR, A. M.; GARTNER, B. R.; MORRELL, J. J. Heartwood formation and natural durability. Wood and Fiber Science, v.34, n.4, p. 587 - 611, 2002.

TONINI, H.; COSTA, M. C. G.; SCHWENGBER, L. A. M. Crescimento da Teca (Tectona grandis) em reflorestamento na Amazônia Setentrional. Pesquisa florestal brasileira, Colombo, n.59, p.5 - 14, 2009.

VIDAURRE, G. B.; LOMBARDI, L. R.; OLIVEIRA, J. T. S.; ARANTES, M. D. C. Lenho juvenil e adulto e as propriedades da madeira. Floresta e Ambiente, Seropédica, v. 18, n. 4, p. 469-480, 2011.

FLORESTA, Curitiba, PR, v. 50, n. 4, p. 1698 - 1706, out/dez 2020.

Canal, W. D. et.al.

ISSN eletrônico 1982-4688 